\title{
The Significance of Localized Financial Factors Which Contribute To Support in Decreasing Project Delay of Real Estate Developer in Selangor, Malaysia
}

\section{Tan Tien Shen, Dania Sammani}

To Link this Article: http://dx.doi.org/10.6007/IJARBSS/v12-i1/12360

DOI:10.6007/IJARBSS/v12-i1/12360

Received: 21 November 2021, Revised: 23 December 2021, Accepted: 08 January 2022

Published Online: 28 January 2022

In-Text Citation: (Shen \& Sammani, 2022)

To Cite this Article: Shen, T. T., \& Sammani, D. (2022). The Significance of Localized Financial Factors Which Contribute To Support in Decreasing Project Delay of Real Estate Developer in Selangor, Malaysia. International Journal of Academic Research in Business and Social Sciences, 12(1), 2810-2819.

Copyright: @ 2022 The Author(s)

Published by Human Resource Management Academic Research Society (www.hrmars.com) This article is published under the Creative Commons Attribution (CC BY 4.0) license. Anyone may reproduce, distribute, translate and create derivative works of this article (for both commercial and non0-commercial purposes), subject to full attribution to the original publication and authors. The full terms of this license may be seen at: http://creativecommons.org/licences/by/4.0/legalcode

Vol. 12, No. 1, 2022, Pg. $2810-2819$

Full Terms \& Conditions of access and use can be found at http://hrmars.com/index.php/pages/detail/publication-ethics 


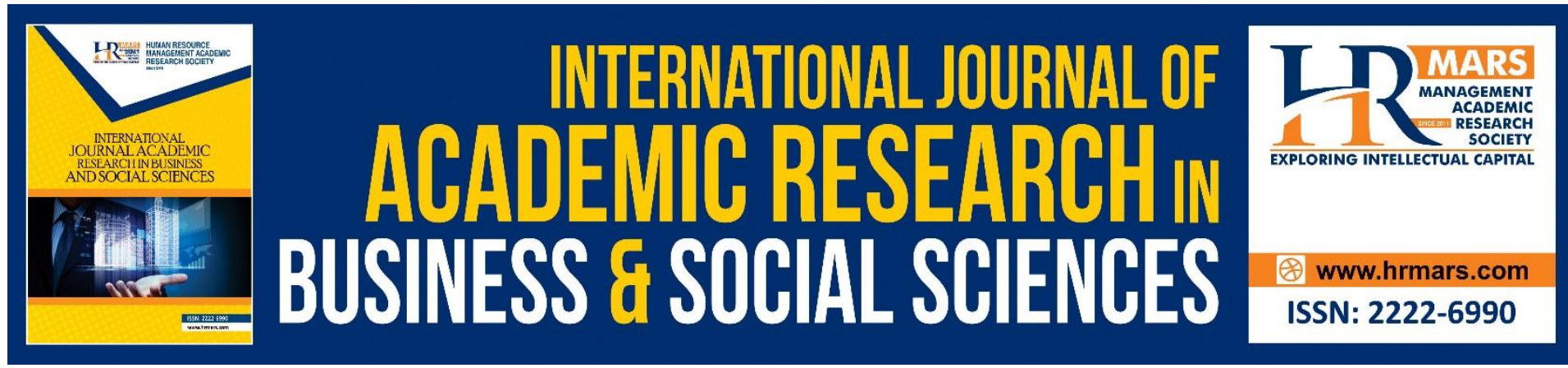

\title{
The Significance of Localized Financial Factors Which Contribute To Support in Decreasing Project Delay of Real Estate Developer in Selangor, Malaysia
}

\author{
Tan Tien Shen, Dania Sammani \\ Tunku Abdul Rahman University College Malaysia
}

\begin{abstract}
Poor project success in work delay among real estate development projects still happening in Malaysia according to statistical records from Ministry of Housing and Local Government Malaysia, despite the evolution and availability of various project management methods in literature (AISehaimi, Koskela, \& Tzortzopoulos, 2013). Therefore there is a need for localized alternatives research approach in project management. The aim of the local alternative research approach is to examine the factors that contribute to reduce project delays by focusing on a number of key factors such as financial factors, in specific, the importance of in depth study of these factors in real estate developer in Selangor, Malaysia. This study also investigated whether the demographic characteristics of the respondents contributed to the assessment differences identified with the success factors of the project. The target group of the study consisted of project managers affiliated with Real Estate Developers in Selangor, Malaysia. A total of 50 respondents were selected for the survey. The result is to develop a conceptual model that could contribute to improve in reducing project delay by studying the financial causes of delay factor specifically in Selected Real Estate Development Company in Selangor, Malaysia with a localized alternative research approach and not a one size fit all conceptual model.
\end{abstract}

Keywords: Project, Delays, Financial, Factors, Real Estate Developer, Selangor, Malaysia, Project Management

\section{Introduction}

Malaysia is a rapidly evolving nation in Asia whose economy has recently been heavily dependent on agriculture, forest ranger service, oil and etc. The shaping of this vision is the result of a contribution in business that depends on the significant and effective success of the operations where Project management in Malaysia is evolving dramatically. Currently it is used in almost all projects, e.g. In government, construction, telecommunications, IT, education and banking. Conscious and effective project management is critical to an organization's success in improving efficiency. The skills and responsibilities of project managers are a source of security, success and capacity for many organizations in Selangor, Malaysia. It is crucial that government could offer and 
advertised as an economic transformation program that require examination of successful project management systems in order to bring the country's economic performance to greater heights. In addition, the future of energy-efficient energy in Malaysia is recognized as the developing company, therefore, this priority is crucial to achieving successful project management in operations.

Even with advances of project management method in the construction industry, delay is undoubtedly a critical factor that can be seen as a critical factor in project performance as researchers give clues about project progress. There are several reasons for the delay and issue of delay, reasons such as "the possible delay in transportation of material", in "Air Terminal Construction Adventure" in the Philippines, machine failure or transmission failure responsible for "Xieng Khouang Road Development", these are reasons and events for delay failures which depends on whether a construction project achieves its goals within the expected costs. Cost invasion is a moderate issue that is almost related to most of the exercises associated with the construction industry. In non-industrialized countries, where these results sometimes exceed some of the typical costs of planned projects, this has become more and more extreme.

Despite the fact that project management methods are basic tools commonly used in the construction industry today, the results of previous research show an impotent track record in managing projects in solving the problems especially problem of costs and delays. Numerous projects have been ineffective that sets standards for cost and time. The main problem is that the project is affected from the originally planned time and ends late. Likewise, the repeated output shows that the problem is not completely solved despite the evolution and availability of various project management methods in literature (AlSehaimi et al., 2013).

According to (Portal Rasmi Jabatan Perumahan Negara, 2021), the housing delay in Selangor is the largest, with 10,951 units of housing affected as of October 2021. A total of 8,008 property buyers in the Malaysian state of Selangor have been impacted by the housing development delays. 


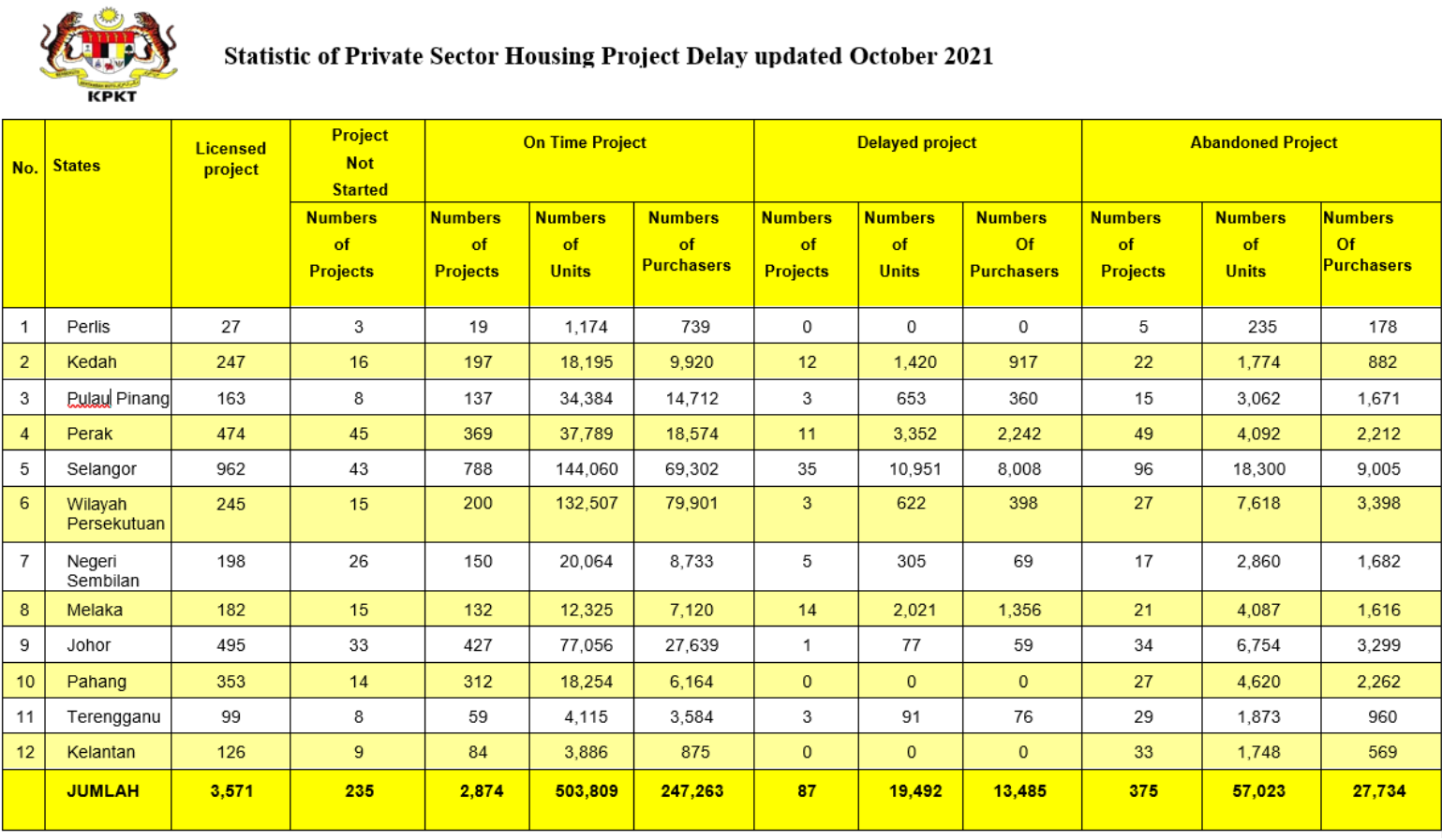

Table 1. Statistic of Private Sector Housing Project Delay (Portal Rasmi Jabatan Perumahan Negara, 2021)

\section{Literature Review}

In Malaysia, Real estate developer plays two major roles on the acquisition of land and the commencement of construction activities. Some developers conduct construction activities through an associated company or select contractors via an open bidding process (Anikeeff \& Sriram, 2008). Real estate developers implement a significant proportion of this private business work, especially when many firms now choose to lease even their company buildings, give them more capacity and reduce borrowing. The developer is the most reluctant member in the supply chain of an innovative product due to perceived risks of acceptance (McCoy et al., 2009). The developer has an enormous obligation to ensure that his/her project is properly accomplished, but unfortunately it is not normally the case. Developer is responsible for in-house design and planning, project finance, project execution/ management, project definition/formulation, legal agreements, schedule urgency and schedule duration, social elements, policy/social factors and contracting with the assistance of consultants (Ezebilo, 2020) stated real estate developers could have a major role in improving cityscapes and assessing environmental consequences. Developers seek regulatory certainty and operational flexibility, while governments seek certainty that environmental, social and infrastructure development conditions to be met by developers (Taylor et al., 2012).

Various causes of delay have been identified over the years that causes project delay in housing project. Among the critical ones are the Organization factors, Project Manager factors and Financial Factors.

In regards to Organization factor (Dissanayake, 2006) organizational construction refers to a process of common consciousness formation that occurs through the interaction of actors to achieve mutually agreed goals. In this sense, the main mechanisms of organizational construction are identified as the interaction of actors, shared sensemaking, and the construction of meaning in the organizational environment. More 
importantly, it presents the view that organizational rationality, organizational effectiveness and efficiency, and the organizational environment are time-bound and contextually constrained constructs. Therefore, all these impact finally resulted in the significant project delay.

In regards to Project Manager factors (Alvarenga et al., 2019), Project manager is a person who in charge of the success of a project in terms of cost and technical performance, he is a leader of a project team and use his knowledge, skills and experiences to ensure the project is completed on time and within the budget (Sumner, 1999). Lack of proper planning and control might cause the work assignments overlap during the construction (Arachchige, 2014). Lack of induction and training of human resources will have significantly negative impact on the work effectiveness (Memon et al., 2014). Failure in making decision and correct action efficiently may result the need for change order due to cost increment and the construction being delayed (Gonfa, 2019). Poor leadership by project manager will directly impact on the lifestyle of the subordinates by causing them become lack of direction and purpose. Therefore, all these impacts finally will bring to the significant project delay.

In regards to Financial Factors. Project financing factor is the most important factor that causes delays and cost overruns because the financing of projects is a serious problem for the construction industry (Frimpong et al., 2003). Unresolved project financing factor will negatively affect client business and financial management (Muya et al., 2013), withhold of payment by client (Booyens et al., 2015) and also contractor's invalid claim (El-Kholy \& Akal, 2019). However the aim of this research is a localized alternative. Therefore, we would breakdown the sub-factors for financial that causes the project delay as follows (Table 2) : 


\begin{tabular}{|c|c|c|c|}
\hline No & Financial Sub-factors & Description & reference \\
\hline 1 & $\begin{array}{l}\text { Client's poor financial } \\
\text { and business } \\
\text { management }\end{array}$ & $\begin{array}{l}\text { Client's poor business and financial management that hinders enhancement in } \\
\text { the delivery of construction projects, such as inadequate preliminary cost } \\
\text { estimates or insufficient allocation of money and inconsistent release of funds } \\
\text { by clients or delayed settlement of interim payment certificates }\end{array}$ & $\begin{array}{l}\text { (Muya, M. et } \\
\text { al. 2014) }\end{array}$ \\
\hline 2 & $\begin{array}{l}\text { Withhold of payment } \\
\text { by client }\end{array}$ & $\begin{array}{l}\text { When the client is in a situation where the cash flow is insufficient, the client } \\
\text { may wish to withhold payment or pay only a certain amount to the contractor } \\
\text { until the cash flow problems are corrected }\end{array}$ & $\begin{array}{l}\text { (Booyens et } \\
\text { al., 2015). }\end{array}$ \\
\hline 3 & $\begin{array}{l}\text { Delay in certification of } \\
\text { interim payment by } \\
\text { consultant }\end{array}$ & $\begin{array}{l}\text { Whether the project is funded by the public sector or the private sector, it is a } \\
\text { common phenomenon to delay the issuance of contractor invoices, because the } \\
\text { process of obtaining payment in Malaysia is very long and complicated }\end{array}$ & $\begin{array}{l}\text { (El-Kholy and } \\
\text { Akal, 2019). }\end{array}$ \\
\hline 4 & $\begin{array}{l}\text { Insufficient } \\
\text { documentation and } \\
\text { information for } \\
\text { valuation }\end{array}$ & $\begin{array}{l}\text { The main reasons for inaccurate valuation include lack of knowledge and } \\
\text { experience of consultants which is related to the availability and interpretation } \\
\text { of information }\end{array}$ & $\begin{array}{l}\text { (Babawale } \\
\text { and Omirin, } \\
\text { 2012). }\end{array}$ \\
\hline 5 & $\begin{array}{l}\text { Involvement of too } \\
\text { many parties in the } \\
\text { process of honouring } \\
\text { certificates }\end{array}$ & $\begin{array}{l}\text { The processing of payment certificates includes more than thirty steps from } \\
\text { invoice to receipt of the paycheque. Any undue delay in honouring payment } \\
\text { certificate will harm the whole project period }\end{array}$ & $\begin{array}{l}\text { (Laryea, } \\
\text { Leiringer and } \\
\text { Hughes, 2011). }\end{array}$ \\
\hline 6 & $\begin{array}{l}\text { Heavy work load of } \\
\text { consultant to do } \\
\text { evaluation for variation } \\
\text { order }\end{array}$ & $\begin{array}{l}\text { Excessive workload, for example, due to intensive work (excessive quantity) in a } \\
\text { limited time frame or inefficient management is one of the sources of } \\
\text { consultant task stress }\end{array}$ & $\begin{array}{l}\text { (Leung et al., } \\
\text { 2005). }\end{array}$ \\
\hline 7 & $\begin{array}{l}\text { Contractor handles too } \\
\text { many projects at the } \\
\text { same time }\end{array}$ & $\begin{array}{l}\text { Project imbalance is the result of working on many projects at the same time, } \\
\text { making it much harder for project managers and project members to focus on } \\
\text { particular work items, and it is asserted that it causes them less able to compete } \\
\text { productively }\end{array}$ & $\begin{array}{l}\text { (Zika- } \\
\text { Viktorsson, } \\
\text { Sundström } \\
\text { and Engwall, }\end{array}$ \\
\hline 8 & $\begin{array}{l}\text { Contractor's unstable } \\
\text { financial background }\end{array}$ & $\begin{array}{l}\text { The financial stability of a contractor refers to their financial status and ability } \\
\text { to manage their finances effectively and continue to fulfil their contractual } \\
\text { obligations without assistance }\end{array}$ & $\begin{array}{l}\text { (UKEssays, } \\
\text { 2018). }\end{array}$ \\
\hline 9 & $\begin{array}{l}\text { Unqualified contractor } \\
\text { underbidding the } \\
\text { project cost }\end{array}$ & $\begin{array}{l}\text { Underbidding means that the contractor's quotation for a bidding project is } \\
\text { lower than the cost involved. Then, the contractor redoubled its efforts to } \\
\text { generate "extra" }\end{array}$ & $\begin{array}{l}(\text { Korczyn, } \\
\text { 1996). }\end{array}$ \\
\hline 10 & $\begin{array}{l}\text { Lack of regularly cash } \\
\text { flow forecasting }\end{array}$ & $\begin{array}{l}\text { Regular cash flow forecasting leads to early recognition of potential cash flow } \\
\text { problems }\end{array}$ & $\begin{array}{l}\text { (John, } \\
\text { Bernard and } \\
\text { Edward, } \\
\text { 2017). }\end{array}$ \\
\hline 11 & $\begin{array}{l}\text { Poor credit } \\
\text { arrangement with } \\
\text { creditors and debtors }\end{array}$ & $\begin{array}{l}\text { Having poor credit means that the company has negative aspects of the credit } \\
\text { history that indicate that the company is a risky borrower }\end{array}$ & (Irby, 2020). \\
\hline 12 & $\begin{array}{l}\text { Difficulties in getting } \\
\text { loan from financiers }\end{array}$ & $\begin{array}{l}\text { Loans are difficult to obtain from financial institutions because they have a } \\
\text { strictly regulated checklist of the financial situation of borrowers }\end{array}$ & $\begin{array}{l}\text { (Abdul- } \\
\text { Rahman, } \\
\text { Takim and } \\
\text { Min, 2009). }\end{array}$ \\
\hline
\end{tabular}

Table 2 : 12 sub-factors of financial causes of project delay

In this study, the critical factors such as organization factors, project manager factors and financial factors are considered as the independent factors of the study while on the other hand project success in reducing delays is dependent upon the Critical factors which resulted as the dependent factor due to the success in reducing project delays. It shows a 
direct cause and effect relationship between independent and dependent factors of the study.

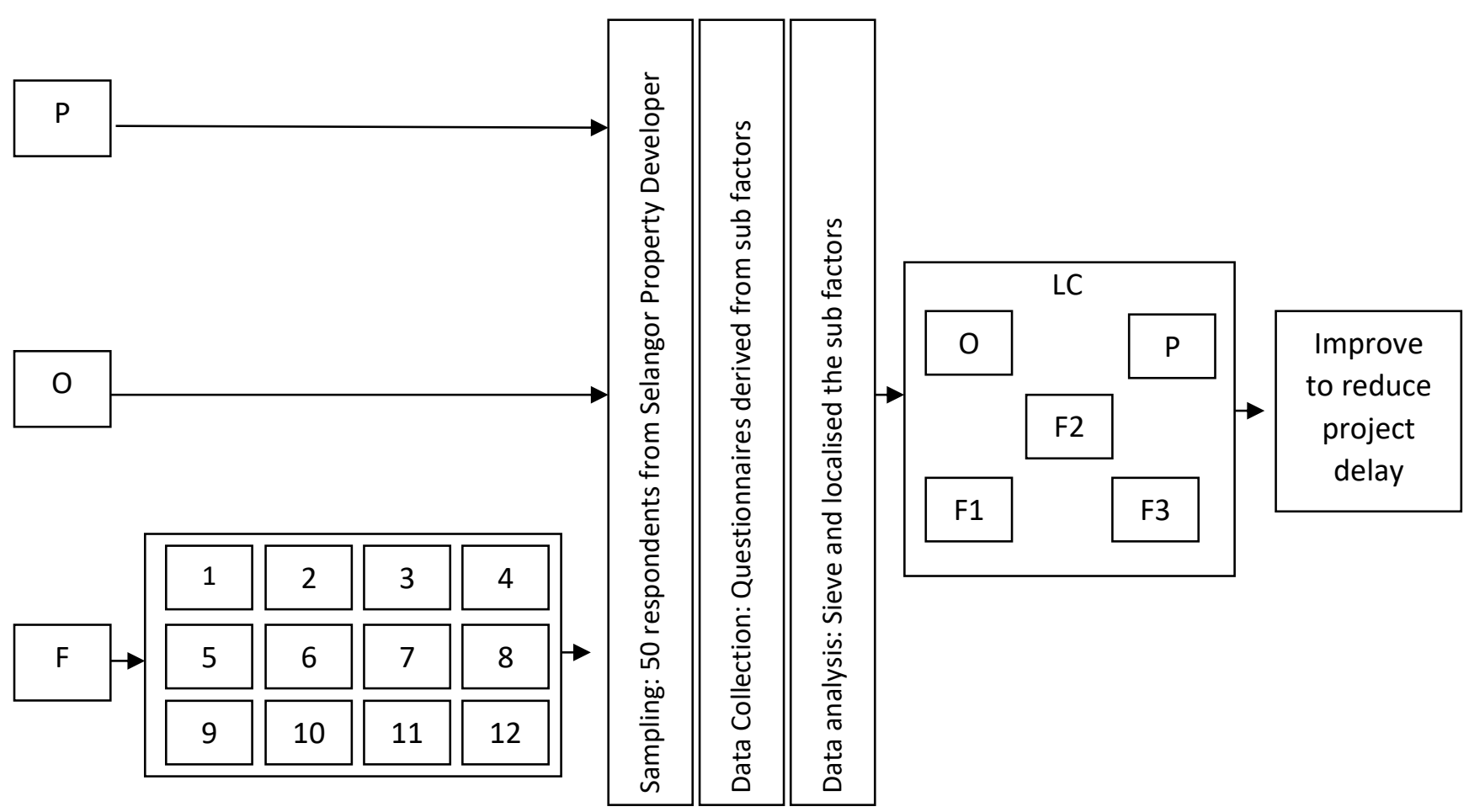

Figure 1. Conceptual Model of study between O(Organization factor ), P( Project Manager factor ), F (Financial factors),1,2,3,4,5,6,7,8,9,10,11,12( Financial subfactor in table 2) and LC( Localized Caused for Project Delay)

Source : Self proposed

This study seeks to gather data on the issue of critical factors to reduce project delay in Selangor, Malaysia using a survey tool that brings together respondents on the three factors examined: (a) Organization factors, (b) Project Manager factors, and (c) Financial factors. The considered population consists of project managers from organizations in Selangor, Malaysia. The purpose of the questions in the tool is to cover all the factors examined. There are 3 factors and 12 subfactors in the study, which examined the 3 factors of organization, project manager and financial. The tool used for this survey is a group of questionnaires that use different scales, including the Likert scale.

The Likert scale asks respondents to respond to a series of proclamations by showing whether they strongly disagree, disagree, neutral, agree, or strongly agree with each statement. Each response is related to a score, and a person's score is determined by adding scores in each link. The questionnaire is divided into two areas as follows: Part 1: consists of 50 questions identified with the 12 sub-factors in table 3. Area 2: contains questions identified by the respondent's demographics, e.g. Gender, ability, long participation times. To collect data on the investigated factors, a study based on table 3 will be used to adapt to the area around Selangor, Malaysia and covers additional aspects that apply to the presented questionaires.

In comparison, survey data is collected manually or sent via email. All corresponding answers are collected in a dataset in Microsoft Excel, which can be used in the statistical 
software package. Statistical Package Social Sciences (SPSS) for Measurable Research. The investigation is performed using descriptive investigation, reliability test and sample t-test. The descriptive research consists of examining the profiles of the respondents. For example, the survey will determine the gender level of the respondents, the time or knowledge of people in project management, and the type of industry.

The 50 respondents were randomly selected from a number of organizations affiliated with project management exercises in real estate developer in Selangor, Malaysia using the following questionnaire in Table 4 derived from Table 3.

\begin{tabular}{|c|c|c|c|c|c|c|}
\hline No & $\begin{array}{l}\text { Question of Financial Sub- } \\
\text { Factors That Causes Project } \\
\text { Delay }\end{array}$ & $\begin{array}{l}\text { Strongly } \\
\text { disagree }\end{array}$ & Disagree & Neutral & Agree & $\begin{array}{l}\text { Strong } \\
\text { Agree }\end{array}$ \\
\hline 1 & $\begin{array}{l}\text { Client's poor financial and } \\
\text { business management }\end{array}$ & & & & & \\
\hline 2 & Withhold of payment by client & & & & & \\
\hline 3 & $\begin{array}{l}\text { Delay in certification of interim } \\
\text { payment by consultant }\end{array}$ & & & & & \\
\hline 4 & $\begin{array}{l}\text { Insufficient documentation and } \\
\text { information for valuation }\end{array}$ & & & & & \\
\hline 5 & $\begin{array}{l}\text { Involvement of too many } \\
\text { parties in the process of } \\
\text { honouring certificates }\end{array}$ & & & & & \\
\hline 6 & $\begin{array}{l}\text { Heavy work load of consultant } \\
\text { to do evaluation for variation } \\
\text { order }\end{array}$ & & & & & \\
\hline 7 & $\begin{array}{l}\text { Contractor handles too many } \\
\text { projects at the same time }\end{array}$ & & & & & \\
\hline 8 & $\begin{array}{l}\text { Contractor's unstable financial } \\
\text { background }\end{array}$ & & & & & \\
\hline 9 & $\begin{array}{l}\text { Unqualified contractor } \\
\text { underbidding the project cost }\end{array}$ & & & & & \\
\hline 10 & $\begin{array}{l}\text { Lack of regularly cash flow } \\
\text { forecasting }\end{array}$ & & & & & \\
\hline 11 & $\begin{array}{l}\text { Poor credit arrangement with } \\
\text { creditors and debtors }\end{array}$ & & & & & \\
\hline 12 & $\begin{array}{l}\text { Difficulties in getting loan from } \\
\text { financiers }\end{array}$ & & & & & \\
\hline
\end{tabular}

Table 3 : Questionnaires derived from Table 2.

\section{Conclusion}

The research was conducted to distinguish the essential financial sub-factors on the effectiveness in reducing of project delay in Selangor, Malaysia. It is widely reported in the literature that organization, project manager and financial factors are critical to the success 
of reducing project delays. In general, several new findings also highlighted the importance of certain critical financial sub-factor that needs to be addressed to minimize delay by using data from 50 respondents in Real estate Developer based in Selangor, Malaysia. By employing the conceptual model in Figure 1, Real estate developers will be able to localize and effectively address the critical sub-factor to reduce project delay for future housing projects in Selangor, Malaysia.

\section{Acknowledgement}

We would like to thank the people involved in making this article published. Not forgetting the faculty and university that trust us. Finally, thanks to our family and friends who have supported us all this time.

\section{Corresponding Author}

Ts. Tan Tien Shen

Department of Quantity Surveying, Faculty of Built Environment, Tunku Abdul Rahman University College

Email: Jtienshen77@gmail.com

\section{References}

\section{Journal Article}

AlSehaimi, A., Koskela, L., \& Tzortzopoulos, P. (2013). Need for Alternative Research Approaches in Construction Management: Case of Delay Studies. Journal of Management in Engineering, 29(4), 407-413. https://doi.org/10.1061/(asce)me.19435479.0000148

Alvarenga, J. C., Branco, R. R., Guedes, A. L. A., Soares, C. A. P., \& Silva, W. da S. (2019). The project manager core competencies to project success. International Journal of Managing Projects in Business, 13(2), 277-292. https://doi.org/10.1108/IJMPB-12-20180274

Anikeeff, M. A., \& Sriram, V. (2008). Construction management strategy and developer performance. Engineering, Construction and Architectural Management, 15(6), 504513. https://doi.org/10.1108/09699980810916951

Arachchige, B. (2014). Absence of Induction and its Impact on the Organization. The IUP Journal of Management Research, (2), 7-16.

Booyens, D., Farrell, S., Garnett, D., \& Perreira, R. (2015). The effect of client interference on construction projects in South Africa. Proceedings of The 3rd Virtual Multidisciplinary Conference, 3(December), 271-278. https://doi.org/10.18638/quaesti.2015.3.1.222

El-Kholy, A. M., \& Akal, A. Y. (2019). Determining the stationary financial cause of contracting firms failure. International Journal of Construction Management, 0(0), 1-16. https://doi.org/10.1080/15623599.2019.1584836

Ezebilo, E. E. (2020). Evaluation of construction, marketing and management in housing delivery by a private developer: evidence from Papua New Guinea. Journal of Housing and the Built Environment, (0123456789). https://doi.org/10.1007/s10901-020-09730-y

Frimpong, Y., Oluwoye, J., \& Crawford, L. (2003). Causes of delay and cost overruns in construction of groundwater projects in a developing countries; Ghana as a case study. International Journal of Project Management, 21(5), 321-326. https://doi.org/10.1016/S0263-7863(02)00055-8

Gonfa, B. D. (2019). Effects of Poor Leadership Skill in Organization : Evidences. Arabian 
Journal of Business and Review, 9(2), 1-5.

McCoy, A. P., Thabet, W., \& Badinelli, R. (2009). Understanding the role of developer/builders in the concurrent commercialization of product innovation. European Journal of Innovation Management, 12(1), 102-128. https://doi.org/10.1108/14601060910928193

Memon, A. H., Rahman, I. A., \& Hasan, M. F. A. (2014). Significant causes and effects of variation orders in construction projects. Research Journal of Applied Sciences, Engineering and Technology, 7(21), 4494-4502. https://doi.org/10.19026/rjaset.7.826

Muya, M., Kaliba, C., Sichombo, B., \& Shakantu, W. (2013). Cost escalation, schedule overruns and quality shortfalls on construction projects: The case of Zambia. International Journal of Construction Management, 13(1), 53-68. https://doi.org/10.1080/15623599.2013.10773205

Sumner, M. (1999). Critical success factors in enterprise wide information management systems projects. Proceedings of the ACM SIGCPR Conference, 297-303. https://doi.org/10.1145/299513.299722

Taylor, B. M., Harman, B. P., Heyenga, S., \& McAllister, R. R. J. (2012). Real estate Developers and Urban Adaptation: Conceptual and Empirical Perspectives on Governance. Urban Policy and Research, 30(1), 5-24. https://doi.org/10.1080/08111146.2011.639178

\section{Online Articles}

Portal Rasmi Jabatan Perumahan Negara. Ehome.kpkt.gov.my. (2021). Retrieved 14 March 2021, from https://ehome.kpkt.gov.my/index.php/pages/view/79. 